\title{
Sustainable development toward sustainable enterprise
}

\author{
Febrizal Rahmana ${ }^{\mathrm{a}}$ and Adhi Bawono ${ }^{\mathrm{a}^{*}}$
}

${ }^{a}$ Bina Nusantara University, Jakarta, Indonesia, Indonesia

\section{H R O N I C L E \\ A B S T R A C T}

Article history:

Received: July 7, 2020

Received in revised format:

August 102020

Accepted: August 17, 2020

Available online:

September 1, 2020

Keywords:

Sustainable Development

Entrepreneur

Entrepreneur orientation

Sustainable enterprise

\begin{abstract}
The concept of sustainable development is inseparable in the business world. In that term, there are three aspects, namely economic, social, and environmental that must be balanced with each other. It is hoped that this concept is needed to know by entrepreneurs in starting their businesses. After that, this business is expected to become a sustainable business that can survive to face the challenges. Mediation input is given in the form of entrepreneurial orientation which can accelerate the creation of sustainable businesses, thus there is a correlation between sustainable development and entrepreneurs. In addition, the entrepreneur variables correlate to entrepreneurial orientation and entrepreneurial orientation has a relationship with sustainable business. In turn, sustainable development, entrepreneurs, entrepreneurial orientation, and sustainable business also deserve further study. This paper examines the relationship between the four variables to the SMEs in Jakarta. Where we want to know how the relationship between the variables of sustainable development with entrepreneurs that aim to achieve sustainable business by mediating entrepreneurial orientation. It also examines the direct comparison between entrepreneurs and sustainable businesses and the relationship between the two variables mediated by entrepreneurial orientation variables. The research data was taken from business operators in Jakarta totaling 245 out of 49 dimensions of the four variables. Data processing is done by structural equation modeling (SEM) through the Lisrel version 8.7 program. Then the calculation results are analyzed based on statistical provisions in getting indications of the relationship between variables. It is found that there is a positive relationship between sustainable development and entrepreneurs, entrepreneurs also have a positive relationship with entrepreneurial orientation, and entrepreneurial orientation has a positive relationship with sustainable business. It turns out that the relationship between entrepreneurs who have gained an understanding of the concept of sustainable development and sustainable business is a significant positive compared to mediating entrepreneurial orientation which remains positive but not significant through the Sobel test that has conducted.
\end{abstract}

C 2021 by the authors; licensee Growing Science, Canada

\section{Introduction}

It is very often that small and medium business owners do not pay attention to aspects of sustainable development in choosing business opportunities. So many of them are constrained in continuing the business. This is due to the imbalance between sustainable components implemented in the business. As an illustration, business actors who only prioritize profits by ignoring environmental sustainability and community rights will have a negative impact on business continuity. In other words, economic, environmental, and social must support and fill each other to make a positive contribution to the business. Therefore, the concept of sustainable development is needed based on Brundlant (1987) has three components, namely economic, social, and environmental where this concept is revealed in his report. Initially, this concept focused on sustainable forest management, but in the 20th century developed into economic development, social development, and environmental protection. Overall, this concept * Corresponding author.

E-mail address: adhi.b@binus.ac.id (A. Bawono) 
aims to keep the next generation from having a source of life. Entrepreneurship is an ongoing process that is also recognized to be a solution to community and environmental problems based on Hall et.al (2010). On the other hand, the relationship between sustainable development and entrepreneurship is still uncertain. The concept of sustainable development must have a balance between economic, social, and environmental, while the entrepreneurs seem difficult to do. Because of all this time, the main objective of the businessman has been to generate maximum profits and they rarely pay attention to social and environmental aspects, conveyed by Maloni and Brown (2006). Over time, Cassar and Friedman (2009) describe that the concept of sustainable development is beneficial for entrepreneurs considering that the availability of raw materials from the environment is limited, and social impacts must also be considered. So, the entrepreneurs are no longer just prioritize the profit. Based on this illustration, it is expected that in conducting business it must have an industry that materials, materials from nature are renewable, then do not damage the environment and do not have a negative impact on people's social lives. This means that entrepreneurs must be observant in choosing the industry, in other words, they do not do business that drains natural reserves, such as coal, oil, mineral mines and also gives environmental damage to mining business excavations which in turn has a negative impact on social life with the onset of economic inequality, economic problems, and local culture.

Although sustainable development and entrepreneurship are still debated how are they related to one another, but these two concepts can be expected to be interconnected, given that there is already evidence of large companies departing from sustainable development thinking to run a business. In this study, the author tries to look at the scope of small and medium businesses. This is driven by curiosity whether the concept of sustainable development has been realized by small and medium business actors. Because they are worried, they look at the success of the business simply by gaining profits, while ignoring environmental and social aspects. For example, small and medium street culinary traders may have a profitable business, but often they do not care about environmental sustainability such as littering, uncontrolled use of plastic bags, also do not pay attention to the sensitivity of social aspects including using underage labor, use ingredients that interfere with health. This if left unchecked is very detrimental to all stakeholders, where the business actor will lose business opportunities, if the business runs it will damage the environment and social order. Even nationally, government efforts in promoting business to provide economic growth cannot run smoothly as expected. By starting a business that contains aspects of sustainable development, it is expected to make a sustainable business as well. Under this matter, there is research that confirms that sustainable development is needed towards sustainable business, among other things. Capra (2002) argues that ignoring the connection between a business and the environment, the business loses many new sustainable development opportunities (SD) which can result in the inevitable collapse of society, then corroborated by Friedman (2005) states since the 1990s, environmental and social factors have become an increasingly important strategic consideration for companies of any size.

From the above review, a relationship can be taken that is sustainable development as a concept that should be owned by entrepreneurs in order to make a sustainable business. By maintaining a balance between economic, environmental, and social aspects. In this research, each sustainable development, entrepreneurship and, sustainable business are the variables to be measured. Where sustainable development as an independent variable related to entrepreneurship as a dependent variable also affects sustainable business which is the dependent variable as the intended outcome. In other studies, it was also shown that entrepreneurial orientation can be a variable related to company performance delivered by Lumpkin and Dess (1996). Then reinforced by Wiklund (1999) that companies that have an entrepreneurial orientation can provide good performance Based on the two studies above, the authors intend to make entrepreneurial orientation as a mediating variable between entrepreneurship and sustainable business. Moreover, added by Jong and Wennekers (2008) that technically for-profit, not-for-profit, or other configurations, a sustainable company includes an integrative vision of its involvement with and its impact on the community and the natural surroundings.

This study has four variables, namely: sustainable development, entrepreneurship, entrepreneurial orientation, and sustainable business. Where there are independent variables, dependent variables and, mediator variables that form a research model. Our first phase will examine the relationship between sustainable development and entrepreneurship, which goes directly to sustainable business. The second phase will also examine the relationship between sustainable development and entrepreneurship towards sustainable business, by placing entrepreneurship orientation as a mediating variable between entrepreneurship and sustainable business. With this, the study was conducted aimed at testing existing theories in expressing relationships between variables. The objectives can be described 
as follows: detect and analyze whether there is a relationship between sustainable development and entrepreneurship; detect and analyze whether there is a relationship between entrepreneurship and entrepreneurial orientation; detect and analyze whether there is a relationship between entrepreneurial orientation and sustainable business; detect and analyze whether there is a direct relationship between entrepreneurship and sustainable business.

The scope of this study is limited to the SME community in Jakarta with a sample of indicators. This research was conducted quantitatively. Then it is expected that the results of the research will provide benefits to the academic world and the business community how the role of sustainable development in sustainable business, therefore the research can open our eyes that sustainable development can be applied to encourage entrepreneurship which in turn contributes to national economic development.

\section{Literature Review}

\subsection{Sustainable development (SD)}

This concept was first offered when the United Nations (United Nations) held a conference on the humane environment in 1972 then continued by the WCED (World Commission for Environment and Development) in 1987 which emphasized that sustainable development must be carried out without compromise so that future generations were still guaranteed their needs. This term is also a problem of Indonesia where sustainable development (Emil Salim, 1990) aims at enhancing social security meeting human needs and expectations. Fundamentally sustainable development intends at equal distribution of development between generations now and in the future. Then the concept of sustainable development continues to develop, even many world companies adopt into the business world by applying financial, environmental and social balance in Elkington's research (1998), known as triple bottom line as a firm's financial, environmental, and social performance.

From the development of the existing arguments, it was agreed that sustainable development must be balanced in three aspects: environment, society, and economy. Strengthened by Harris (2000) see that the sustainability definition can be broken down into three aspects of understanding, as follows:

A. Economic stability is described as the development capability of continuously producing goods and services in order to retain government sustainability and to prevent the occurrence of sectoral inequalities that can damage agricultural and industry.

B. Environmental sustainability that the framework of environmental sustainability must be capable of preserving healthy resources, preventing the misuse of natural resources and environmental absorption process and, also involves the conversation of biodiversity, airspace stability, and other ecosystem functions which are not included in the economic resources group.

C. Social sustainability, social sustainability is described as a capability to achieve equality, social services delivery including health and education.

The development of the concept of sustainable development can be said to be full of controversy. Starting with a difference of opinion that companies must benefit without regard to environmental and social concerns. After that, environmental activists urged that the company also be obliged to maintain the place where they do business. Then proceed with the company's obligation to provide benefits to the surrounding community. In the end, this concept must have three aspects namely economic, environmental, and social with the aim of getting a decent profit by preserving the environment and taking into account the viability of people's lives.

In line with the above concept, Sutamihardja (2004), states that sustainable development targets include the efforts to realize the occurrence of several factor as follow: a. Benefits distribution equality of intergenerational development outcomes (intergeneration equity); b. Safeguarding or safeguarding natural resources and the existing environment preservation also preventing the occurrence of ecosystem disturbances in the context of ensuring life for future generations; c. Utilization and management of natural resources only for the sake of pursuing economic growth in the interest of equitable distribution of sustainable use of natural resources between generations; $d$. Maintaining the welfare of the people (community) which is sustainable both now and in the future (intertemporal); e. Maintaining the benefits of development or the management of natural and environmental resources that have long-term or sustainable long-term benefits between generations; f. Maintaining the quality or quality of human life between generations in accordance with their habitat. In addition, according to Yaghoobi et al. (2010) entrepreneurs dare to get an open, independent and a productive breakthrough. Therefore, the importance of entrepreneurship is a must to create something new and different from opportunities. 


\subsection{Entrepreneur (EN)}

Baldacchino (2008) stated that entrepreneurship is about a creative and innovative ability in order to have tips, and resources in finding opportunities for success. That is why the two terms of creativity and innovation are needed as all entrepreneur. The entrepreneur is someone who is always innovated in anticipating the situation, initiative in acting and the important thing is to take risks and be profit-oriented delivered by Isa (2011). According to entrepreneurial competence, Suryana (2003) explains below:

a. Managerial skills, entrepreneurs should be able to carry out tasks in planning, management, supervision and action so that business objectives can be achieved.

b. Conceptual skills, the ability of entrepreneurs to set goals, policies, and strategies trying to achieve success c. Human Skills, entrepreneurs have expertise in socializing such as sociable, sympathy and, empathy for their partners. This is a supportive capital in success as an entrepreneur. Having this expertise is expected to have many opportunities in pioneering and developing its business.

d. Decision-making skills, an entrepreneur can analyze situations and solve problems in anticipation of uncertainty. e. Time managerial skills, a skill possessed by someone in to manage the time to achieve the plans they made.

The above five dimensions of the entrepreneurial variable will include indicators outlined in the research questionnaire.

\subsection{Entrepreneurial Orientation (EO)}

The study of orientation conducted by Stevenson and Jarillo (1990) discusses the analogy of management concepts concerning the methods, processes, and behavior of organizations in entrepreneurship.

This variable itself has been studied by Miller (1983), Covin and Slevin (1989), and Lumpkin and Dess (1996) who say that this is included in entrepreneurial behavior, which divides this variable into three dimensions as follows: a. Innovation means always trying to improve efficiency, effectiveness and, productivity in every aspect of activities and vigilance in facing business competition; $b$. Proactive means always having initiative and not waiting, and thinking visionary so that you have to plan every time; c. Risk management is the courage to take risks and adjust the risk profile and know the risks and benefits of a business.

After adding two more dimensions still by Lumpkin and Dess (2005), concluded that to increase entrepreneurial success must be supported by EO, as follows: d. Autonomy means that entrepreneurs must freely make decisions not limited by internal and external aspects; e. Aggressive means having to have a strong desire to compete in facing challenges to seize opportunities.

From the explanation above, on this occasion, the entrepreneurial orientation consists of the five dimensions above which are the basis for the authors to make a research questionnaire. Then the five dimensions are also recognized by Wiklund and Shepherd, D. (2003).

\subsection{Sustainable Enterprise (SE)}

A Sustainable business that is commonly referred to as sustainable enterprise excellence or SEE can also be called a sustainable company researched by Shrivastava and Hart (1995). If the concept of sustainable development is known as the triple bottom line (TBL), which is 3P (planet, people, and profit), those three aspects must be balanced with each other. So, the concept of sustainable business (sustainable enterprise) there is additional aspects of $3 \mathrm{E}$ (ethics, effectivity, efficiency) as conveyed by McDonough and Braungart (2002), hereinafter known as the triple top line (TTL) concept. Thus, now the SEE has six dimensions namely self-capital, ecology, economy, environment, society, and profit. Below, the author will explain each of these dimensions: a. Ethics: values of life that become standards are based on moral judgment; $b$. Effective: choose the correct method; $c$. Efficient: do things right. These three dimensions, according to Eskildsen et al. (2018), constitute a group of governance in a sustainable enterprise. Where the three dimensions cannot be separated must exist in the concept of sustainable development which has been discussed in the previous variable. While the concept of sustainable development consisting of the environment, society, and profits in the same research is grouped as strategic dimensions. Thus, 3E known as TTL and 3P known as TBL can be united into six interrelated dimensions in order to get a sustainable enterprise. So, in other words, based on this theory a sustainable company is not only a triple bottom line strategy but also must have a triple top line arrangement. 
Aspects of the four variables that have been reviewed based on the literature review above can be used as the dimensions described in the research indicators. Thus, for the next step, a research framework is needed that illustrates the proposed relationship between the variables that exist both directly and mediated.

\subsection{Research Framework}

The four variables namely sustainable development (SD), entrepreneur (EN), entrepreneurship orientation (EO), and sustainable enterprise (SE) below, the authors set the research framework as follows:

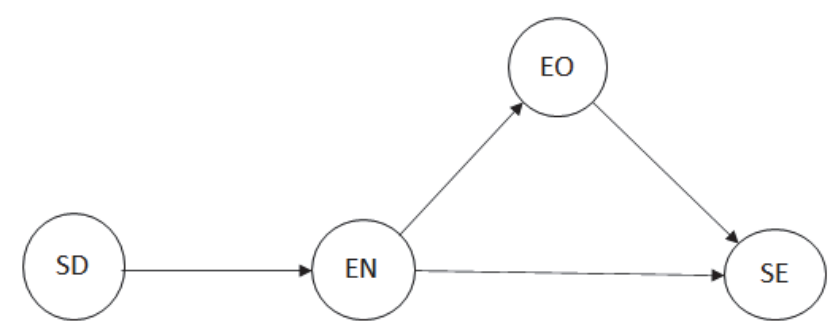

Fig. 1. Model framework

So, we get the relationship between variables from the above framework with several research hypotheses, as below:

a. Hypothesis-1: A positive relationship exists between the variable of sustainable development and the entrepreneur variable.

b. Hypothesis-2: There is a positive relationship between the entrepreneur variable and the entrepreneurship orientation variable.

c. Hypothesis-3: A positive relationship exists between the entrepreneurship orientation variable and the sustainable enterprise variable.

d. Hypothesis -4: There is a positive relationship between the entrepreneur variable and the enterprise sustainable variable.

\section{Research Methods}

\subsection{Research Design}

This study was designed based on causality relationships where the relationships between variables are interrelated with one another. The Sustainable Development (SD) variable is an exogenous variable, the Entrepreneurship variable (EN) is endogenous and exogenous, the Entrepreneurship Orientation (EO) variable is also an exogenous and endogenous variable and the Sustainable Enterprise (SE) variable is endogenous. The relationships examined are the relationship between the SD variable and the EN variable then to the SE variable, which is mediated by the EO variable. It also saw a direct relationship between the EN variable and the SE variable. This research uses quantitative methods to measure the nature of influence between variables with each other. What is quantified is the perception of the company's stakeholders as the object of study. Their perception is measured on a Likert scale, consisting of 5 choices with the following explanation: 1 for strongly disagree, 2 for disagree, 3 for agree, 4 for very agree, 5 for very much agree.

\subsection{Purpose Sampling}

The sample size used was obtained from respondents as much as 5 times the number of indicators that exist in Jakarta's small and medium businesses. These indicators come from variables that cannot be detected directly or are known as unobserved variables. This large size is in view of the structural equation model which is estimated using LISREL by requiring a size of $\mathrm{n} \geq 150$ (Wijaya, 2013; Feldman \& Francis, 2004).

\subsection{Validity and Reliability}

The validity of the statements contained in the questionnaire is tested using the statistical method in which each statement is correlated with the total score of the statement. The statement item is said to be valid if $r \geq 0.30$ 
(Sekaran, 2003). The entire questionnaire was tested for its reliability (reliability) with the Cronbach Alpha value $\geq 0.6$ (Latan, 2013).

\subsection{Operational Variables}

The four sustainable development (SD), entrepreneur (EN), Entrepreneurial Orientation (EO), and sustainable enterprise (SE) research variables are tabulated based on dimensions and indicators following the journals in the literature review. SD consists of 3 dimensions and 10 indicators, EN consists of 5 dimensions and 14 indicators, while EO itself has 5 dimensions over 15 indicators, plus SE over 3 dimensions there are 10 indicators. These relationships are a picture of the model framework of this study in which there are four hypotheses to be tested. Then a questionnaire was answered by respondents with a Likert scale. A description of the construct group, dimensions, indicators and switches can be seen in Table 1 as follows,

\section{Table 1}

Research variable

\begin{tabular}{|c|c|c|c|c|}
\hline $\mathrm{NO}$ & Construct & Dimension & Indicators & Scale \\
\hline \multirow{3}{*}{1} & Sustainable Development var- & Economic & 4 & Likert(interval) \\
\hline & iable & Social & 3 & Likert(interval) \\
\hline & (SD) & Environment & 3 & Likert(interval) \\
\hline \multirow{5}{*}{2} & \multirow{5}{*}{$\begin{array}{c}\text { Entrepreneur variable } \\
(\mathrm{EN})\end{array}$} & Managerial & 3 & Likert(interval) \\
\hline & & Conceptual & 3 & Likert(interval) \\
\hline & & Human resource & 3 & Likert(interval) \\
\hline & & Decision making & 3 & Likert(interval) \\
\hline & & Time management & 2 & Likert(interval) \\
\hline \multirow{5}{*}{3} & \multirow{5}{*}{$\begin{array}{c}\text { Entrepreneurship Orientation } \\
\text { variable } \\
(\mathrm{EO})\end{array}$} & Innovation & 3 & Likert(interval) \\
\hline & & Proactive & 3 & Likert(interval) \\
\hline & & Risk Management & 3 & Likert(interval) \\
\hline & & Autonomy & 3 & Likert(interval) \\
\hline & & Aggressiveness & 3 & Likert(interval) \\
\hline \multirow{3}{*}{4} & \multirow{3}{*}{$\begin{array}{l}\text { Sustainable Enterprise Varia- } \\
\text { ble } \\
\text { (SE) }\end{array}$} & Ethic & 3 & Likert(interval) \\
\hline & & Effective & 4 & Likert(interval) \\
\hline & & Efficient & 3 & Likert(interval) \\
\hline
\end{tabular}

To facilitate the calculation of the Lisrel program, the SD notation changes from X1 to X10, EN changes to Y1 to Y14, EO becomes W1 to W15 and SE from Z1 to Z10. The number of notations for each variable is equal to the number of indicators for each variable. The following are the elaboration of the indicators for each of the SD, EN, EO and SE variables.

\section{$\underline{\text { Sustainable Development }}$}

$\mathrm{SD} 1=\mathrm{X} 1 \quad$ Entrepreneurs are profit-oriented

$\mathrm{SD} 2=\mathrm{X} 2 \quad$ Business capital is important

$\mathrm{SD} 3=\mathrm{X} 3 \quad$ Prioritizing positive cash flow

SD $4=\mathrm{X} 4 \quad$ Sales are important

SD $5=\mathrm{X} 5 \quad$ Provide employment opportunities to the surrounding community

SD $6=\mathrm{X} 6 \quad$ Provide compensation if the business benefits

SD $7=\mathrm{X} 7 \quad$ Entrepreneurship is beneficial for all relevant stakeholders.

SD $8=$ X8 Entrepreneurship can have a positive impact on environmental sustainability.

SD $9=$ X9 Entrepreneurship can make the environment cleaner

SD10 $=$ X10 Survival of business environmental interests.

\section{Entrepreneur}

EN $1=$ Y1 Plan everything in the business

EN $2=$ Y2 Implement effective business management

EN $3=$ Y3 $\quad$ Perform periodic control

EN $4=$ Y $4 \quad$ Cultivating reading

EN $5=$ Y $5 \quad$ Cultivating writing

EN $6=\mathrm{Y} 6 \quad$ Cultivating discussion

EN $7=$ Y7 $\quad$ Leadership in management

EN $8=$ Y8 Active communication on all lines of management

EN $9=$ Y9 Upholding the principle of accountability in management

EN $10=$ Y10 Analyze problem solving

EN $11=$ Y11 Perform synthesis in formulating solutions

EN $12=$ Y12 Think strategically

EN $13=$ Y13 Uphold discipline in management

EN14 $=$ Y14 Be consistent in achieving achievements 
Entrepreneurial Orientation

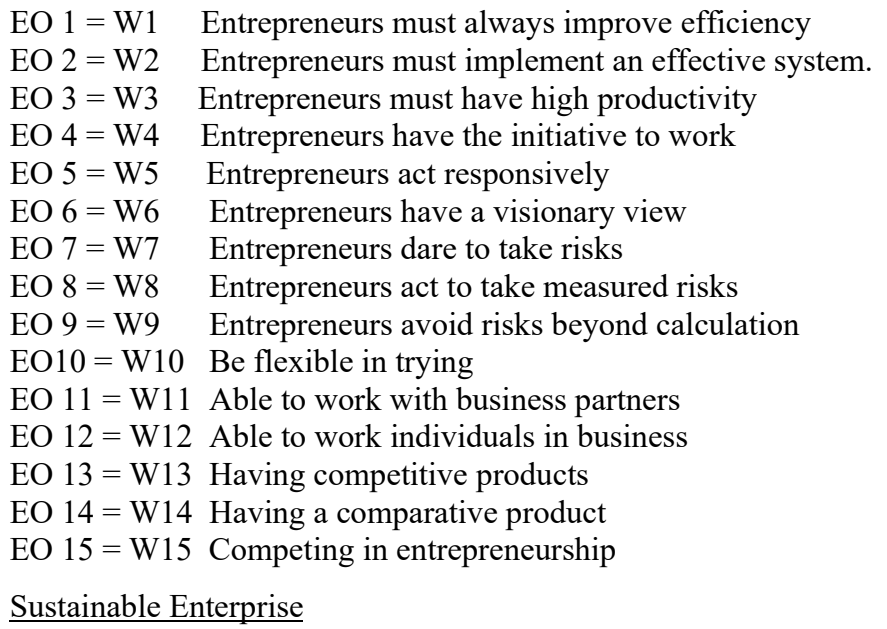

SE $1=$ Z1 Contributes to the Social, economic and environmental Sustainability factors

$\mathrm{SE} 2=\mathrm{Z} 2 \quad$ Organizations focus on change and innovation

$\mathrm{SE} 3=\mathrm{Z3} \quad$ Changes needed to be implemented

SE $4=Z 4 \quad$ Build existing HR competencies

SE $5=$ Z5 Invests in social, economic and environmental of sustainability factors

SE $6=Z$ Z Investing in building HR competencies

$\mathrm{SE} 7=\mathrm{Z7} \quad$ Improvements in financial performance in business

SE $8=Z 8 \quad$ The existence of improvement in community sustainability

SE $9=Z 9 \quad$ Innovation results related to society and the environment

$\mathrm{SE} 10=\mathrm{Z} 10 \quad$ Innovated of business model

\subsection{Data Analysis Methods}

In the framework of thought presented in Fig. 2, it appears that the variables available when presented in the form of mathematical equations will be in the form of structural equations known as Structural Equation Models (SEM). There are several SEM programs, including LISREL or AMOS software. Explanation of the steps in a sequential analysis below, as follows:

a. SUB MODEL loading factor and t-values test

To test the sub-models of each variable, the sub-models are formed first, namely: SD Sub Model with 10 existing indicators; EN Model sub with 14 indicators; EO sub-model with 15 indicators; SE sub-model with 10 indicators. All indicators are derived from the dimensions of each variable. After that, a loading factor and t values test is performed and the calculation results of these two tests are analyzed how each indicator contributes to the related variable.

b. FULL MODEL loading factor and t-values test

The complete model below is a combination of sub-models by following the framework that is in this study. Where all indicators of latent variables for SD, EN, EO and SE are labeled in one complete model. With complete model drawings as follows:

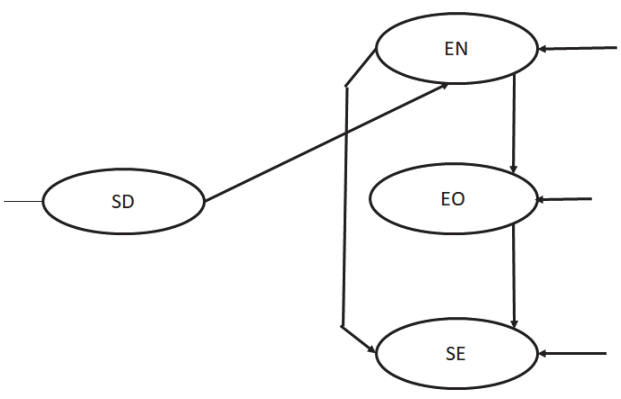

Fig. 2. The structure of full model

When the tests are completed, criteria for goodness fit will emerge, where researchers can determine the extent to which sub models and complete models meet SEM criteria with the Lisrel program. These criteria are chi square, df, p-value and RMSEA. Then it can be seen how the results of the above tests of loading factors and t-values. As a condition of loading factor must be greater or equal to 0.5 then the indicator significantly affects the sub-model. And, the variables that exist have a significant relationship between variables in the full model. If the t-value is greater than or equal to 1.96 then the indicator 
is also significant for the sub-model, also for the complete model both tests are also performed to see the relationship between variables whether significant or not.

\subsection{Hypothesis Testing}

The form of hypothesis testing in this study is as follows (Wijaya, 2013): to test the effect of the independent variable used the $t$ test, which serves to test the significance of the coefficient partially. Testing through test is done by comparing t-counts with t-tables at a significant degree of $5 \%$. With the statistical standards as follows;

a. $\quad \mathrm{t}$-count $>\mathrm{t}$-table then $\mathrm{H} 0$ is rejected and $\mathrm{H} 1 \ldots \mathrm{n}$ is accepted, which means that the dependent variable can explain the independent variable, and indeed there is a significant influence between the two variables tested.

b. $\quad \mathrm{t}$-count $<\mathrm{t}$-table then $\mathrm{H} 0$ is accepted and $\mathrm{H} 1 \ldots \mathrm{n}$ is rejected, which means that the dependent variable can explain the independent variable and there is no significant effect between the two variables tested.

And, test $\alpha$ significance level $=5 \%$. Testing at the 5\% level. With the calculation results show as follows:

a. The probability of error is less than 5\%, then $\mathrm{H} 0$ is rejected and $\mathrm{H} 1 . . \mathrm{n}$ is accepted. This shows that there are significant differences in each variable.

b. The probability of error is more than $5 \%$, then $\mathrm{H} 0$ is accepted and $\mathrm{H} 1 \ldots \mathrm{n}$ is rejected. This shows that there is no significant difference in each variable.

\section{Results and Discussion}

\subsection{Validation and Reliability}

The results of the statistical test of the validity and reliability of the questionnaire for the SD latent variable (constructs) that appear in items X1 to X10 have a corrected item-total correlation greater than 0.3 except X2, so the items above are all valid. The Cronbach Alpha for SD data is also above 0.828, thus feasible as a variable. For the latent variable EN, it appears that the corrected item correlations are all greater than 0.3 . Thus, there are no dropping indicators on this variable, while the Cronbach alpha is also above 0.942 where this variable is considered feasible. The latent variables EO with the corrected item total correlation are all still greater than 0.3 so all are valid. And the Cronbach alpha value of 0.932 which can be said to be feasible as a variable. The latent SE variables with the corrected item total correlation are all still greater than 0.3 so all are valid. And the Cronbach alpha value of 0.927 which can be said to be feasible as a variable.

\subsection{Calculation of loading factors and}

Below are the results of the calculation of the loading factor and t-test of each variable: SD, EN, EO and SE. Then there are also the results of a complete model calculation for loading factors and t-test.

Table 2

EO sub-model calculation results

\begin{tabular}{|c|c|c|c|c|c|c|c|c|c|c|}
\hline & $\mathrm{X} 1$ & $\mathrm{X} 2$ & $\mathrm{X} 3$ & $\mathrm{X} 4$ & $\mathrm{X5}$ & X6 & X7 & $\mathrm{X} 8$ & X9 & $\mathrm{X} 10$ \\
\hline Loading factor & 0.50 & 0.28 & 0.65 & 0.59 & 0.49 & 0.66 & 0.76 & 0.69 & 0.47 & 0.66 \\
\hline$t$ test & 7.75 & 4.15 & 10.78 & 9.52 & 7.68 & 10.82 & 13.19 & 11.55 & 7.18 & 10.92 \\
\hline
\end{tabular}

In Table 2, X2 as Business capital is important, X5 as sales are important and X9 as Entrepreneurship can make the environment cleaner show loading factor values below 0.5 , which means that the three indicators do not significantly affect the SD variable. But this result is ignored by the t-test value where all indicators show values above 1.96 which means the ten indicators significantly affect the SD variable.

Table 3

EN model sub model calculation results

\begin{tabular}{ccccccccccccccccc}
\hline & $\mathrm{Y} 1$ & $\mathrm{Y} 2$ & $\mathrm{Y} 3$ & $\mathrm{Y} 4$ & $\mathrm{Y} 5$ & $\mathrm{Y} 6$ & $\mathrm{Y} 7$ & $\mathrm{Y} 8$ & $\mathrm{Y} 9$ & $\mathrm{Y} 10$ & $\mathrm{Y} 11$ & $\mathrm{Y} 12$ & $\mathrm{Y} 13$ & $\mathrm{Y} 14$ \\
\hline Loading factor & 0.75 & 0.79 & 0.76 & 0.56 & 0.36 & 0.62 & 0.79 & 0.83 & 0.76 & 0.81 & 0.83 & 0.85 & 0.82 & 0.76 \\
$\mathrm{t}$ test & 13.7 & 14.82 & 13.80 & 9.40 & 5.65 & 10.65 & 14.57 & 15.90 & 13.81 & 15.12 & 15.70 & 16.42 & 15.66 & 13.79 \\
\hline
\end{tabular}

Table 3 shows that only Y 5 as cultivating writing has a loading factor of 0.36 , meaning that this indicator does not significantly affect the EN variable. Even based on t-test, all indicators are valued at bag 1.96, so these 14 indicators affect the variable significantly.

Table 4

EO sub-model calculation results

\begin{tabular}{cccccccccccccccc}
\hline & W1 & W2 & W3 & W4 & W5 & W6 & W7 & W8 & W9 & W10 & W11 & W12 & W13 & W14 & W15 \\
\hline Loading factor & 0.72 & 0.78 & 0.77 & 0.79 & 0.81 & 0.76 & 0.73 & 0.75 & 0.51 & 0.59 & 0.80 & 0.59 & 0.75 & 0.60 & 0.42 \\
t test & 12.88 & 14.31 & 13.97 & 14.67 & 15.24 & 13.85 & 13.18 & 13.65 & 8.38 & 9.91 & 14.91 & 9.95 & 13.60 & 10.19 & 6.76 \\
\hline
\end{tabular}

The table states that only W15 as competing in entrepreneurship does not significantly influence the variable with a loading 
factor value of 0.420 . But by t test all indicators are above 1.96 , so all variables can be said to have a significant impact on the EO variable.

Table 5

SE sub model calculation results

\begin{tabular}{cccccccccccc}
\hline & $\mathrm{Z} 1$ & $\mathrm{Z} 2$ & $\mathrm{Z} 3$ & $\mathrm{Z} 4$ & $\mathrm{Z} 5$ & $\mathrm{Z} 6$ & $\mathrm{Z} 7$ & $\mathrm{Z} 8$ & $\mathrm{Z}$ & & $\mathrm{Z} 10$ \\
\hline Loading factor & 0.66 & 0.69 & 0.74 & 0.81 & 0.84 & 0.80 & 0.79 & 0.71 & 0.72 & 0.72 \\
$\mathrm{t}$ test & 11.40 & 11.96 & 13.36 & 15.20 & 16.1 & 14.85 & 14.60 & 12.47 & 12.86 & 12.68 \\
\hline
\end{tabular}

From the Table 5, the two loading factor tests and the t test of all the indicators show the above results, which are 0.50 and 1.96. Thus 10 indicators have a significant influence on the variable SE. Significance requirements are valid for all lines, SD to EN with a coefficient of 0.81 , EN to EO with a coefficient of 0.890 , EO to SE has a coefficient of 0.04 and EN to SE directly has a coefficient of 0.790 . From the results above prove the role of EO as a weak mediator is not significant, whereas if the EN variable goes directly to the SE variable has a significant relationship. Under this t-test will be calculated from the full model, with the results attached below.

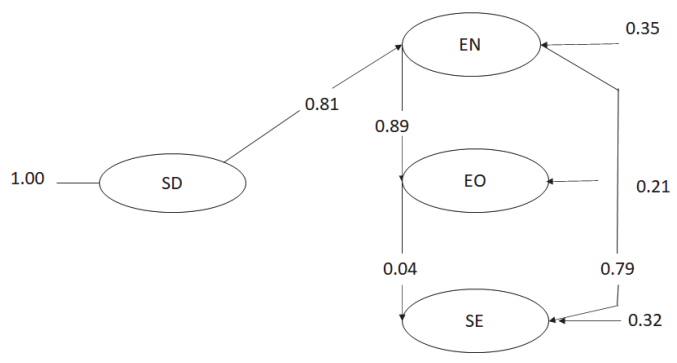

Fig. 3. Loading Factor Full Model

The results of the full model are strengthened by t-test with the following values. the relationship between SD to EN t test was 11.32 then EN to EO t test results were 11.12 followed by EO to SE the t-test was 0.370 . And, the EN to SE link directly t-test results showed 6.09. Thus the t-test, the relationship between the EN and SE variables is directly significant, but the EO variable does not prove to be a significant mediator between the EN variable and the SE variable.

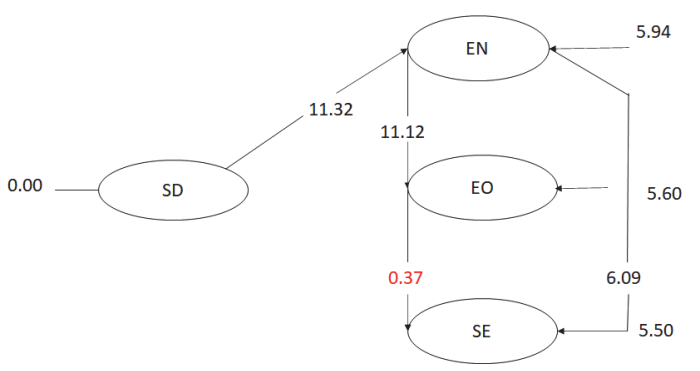

Fig. 4. The results of t-values

After testing the validity and reliability of all questionnaires as well as the loading factor as well as the t-test of the sub models and the complete model all relationships are expected to be used to answer the research hypotheses, as follows:

a. Hypothesis-1: There is a positive relationship between the sustainable development variable and the entrepreneur variable, accepted

b. Hypothesis-2: There is a positive relationship between the entrepreneur variable and the entrepreneurship orientation variable, accepted

c. Hypothesis-3: There is a positive relationship between the entrepreneurship orientation variable and the sustainable enterprise variable, accepted but not significant

d. Hypothesis -4: There is a positive relationship between the entrepreneur variable and the sustainable enterprise variable, accepted

\subsection{Discussion}

In the sustainable development sub-model, the indicator that gives the biggest contribution is 0.647 , which is beneficial for all relevant entrepreneurs. While the indicator that gave the lowest contribution was 0.274 , which is an important business capital. However, overall these indicators have significant validity and reliability. In loading factors there are four indicators 
below 0.5 , namely profit-oriented entrepreneurs (X1), business capital is important (X2), trying to provide employment opportunities for others (X5) and entrepreneurship to provide environmental health (X9). From the t-test all indicators meet the requirements of more than 1.98 so it can be said that this sub-model is significant.

In the entrepreneur sub-model that provides the largest contribution is an indicator of entrepreneurs always think strategically in answering challenges, with a value of 0.81 . While indicators of entrepreneurship in writing are given the lowest role with a value of 0.387 . For loading factor, only indicators of entrepreneurs who write culture (Y5) whose values are below 0.5 , but in the $t$ test all indicators above 1.98 get said that this sub-model is also significant.

All indicators of the entrepreneurship orientation sub model that contribute significantly because validity and reliability meet the requirements. The loading factor is only an indicator of competition in business (W15) which is below 0.5 . But in the $t$ test all indicators are significant to the variable. So it can be said that the entrepreneurship orientation sub model is feasible as a variable. All indicators of the entrepreneurship orientation sub model provide a significant role because validity and reliability meet the requirements. Likewise, the loading factor and t-test all indicators meet the significant requirements. So this sub-model is also feasible as a variable. In the complete model, the results of the loading factor and t-test show that there is a significant relationship between $\mathrm{SD}$ variable and $\mathrm{EN}$ variable, EN variable and $\mathrm{EO}$ variable, EN variable and SE variable. But there is no significant relationship between the EO variable and the SE variable. Thus EO does not become a mediator variable the relationship between the EN variable and the SE variable.

\section{Conclusion and Implications}

Based on the analysis and discussion, the study has concluded that SME entrepreneurs are expected to first understand the concept of sustainable development in order to be able to become entrepreneurs who are insightful of the concept. And, in turn, they can transform into a sustainable effort over time. Although there are entrepreneurial orientation variables that should be able to mediate the relationship between entrepreneurs and sustainable business variables, the results of the study have not shown a significant role. The insignificance of the mediator has been evidenced by testing the loading factor of the relationship between entrepreneurs and entrepreneurial orientation, as well as entrepreneurial orientation and sustainable business which are 0.890 and 0.040 , respectively. The relationship between entrepreneurs and sustainable businesses yields a value of 0.790 . Thus, with a single test, the coefficient of EN to EO and EO to SE is directly below the coefficient of EN to SE. Likewise, the t-test for the statistical value of the relationship between entrepreneurs and entrepreneurial orientation is above 1.98, but between entrepreneurial orientation and sustainable business does not qualify. The relationship between entrepreneurs and sustainable businesses directly has a significant t-test score of 6.09. Thus, to make a sustainable business, it is necessary to have an entrepreneur who has a concept of sustainable development. The results of this study have contributed to economics, namely sustainable development and can be used as a reference for cooperatives in playing a significant role in the organization of cooperative members to become competent entrepreneurs. It is hoped that this input will become a national program for all cooperatives in Indonesia to activate the role of cooperatives as mediators to increase the number of national entrepreneurs. The results of this study can also provide input for cooperative organizations to improve managerial abilities in empowering all their potential. In turn, all potentials will become an organizational asset to realize the mediating role. Therefore, all cooperatives will contribute significantly internally.

\section{Acknowledgment}

We thank Bina Nusantara University for funding this research. The author also would like to thank the anonymous referees for constructive comments on the earlier version of this paper.

\section{References}

Baldacchino. (2008). Entrepreneurial creativity and innovation. The First International Conference on Strategic Innovation and Future Creation, University of Malta, Malta.

Cassar, G., \& Friedman, H. (2009). Does self-efficacy affect entrepreneurial investment?. Strategic Entrepreneurship Journal, 3(3), 241-260.

Covin, J. G., \& Slevin, D. P. (1989). Strategic management of small firms in hostile and benign environments. Strategic Management Journal, 10(1), 75-87.

Eskildsen, J. K., Edgeman, R., Mønster, D., \& Olesen, J. V. (2013). Response Based Segmentation in Satisfaction Surveys. In Performance Management Association Australasia Conference.

Feldman, M. P., \& Francis, J. L. (2004). Homegrown solutions: Fostering cluster formation. Economic Development Quarterly, 18(2), 127-137.

Hall, J. K., Daneke, G. A., \& Lenox, M. J. (2010). Sustainable development and entrepreneurship: Past contributions and future directions. Journal of Business Venturing, 25(5), 439-448.

Harris, M. (2000). Human Resource management. $2^{\text {nd }}$ ed. USA : Harcourt Brace \& Company.

Jong, W., \& Wennekers, S. (2008). Conceptualizing entrepreneurial employee behavior. SMEs and Entrepreneurship Programme Finance by the Netherlands Ministry of Economic Affairs.

Latan, H. (2013). Model Persamaan Struktural Teori dan Implementasi AMOS 21.0. Bandung, Alfabeta.

Lumpkin, G. T., \& Dess, G. G. (1996). Clarifying the entrepreneurial orientation construct and linking it to performance. Academy of Management Review, 21(1), 135-172. 
Lumpkin, G., \& Dess, G. G. (2005). Linking two dimensions of entrepreneurial orientation to firm performance: Moderating role of environment industry life cycle. Journal of Business Venturing, 16, 429-451.

Maloni, M. J., \& Brown, M. E. (2006). Corporate social responsibility in the supply chain: an application in the food industry. Journal of Business Ethics, 68(1), 35-52.

Miller, D. (1983). The correlates of entrepreneurship in three types of firms. Management Science, $29(7), 770-791$.

Isa, M. (2011). Analisis Kompetensi Kewirausahaan, Orientasi Kewirausahaan, dan Kinerja Industri Mebel.

Salim, E. (1990). Konsep Pembangunan Berkelanjutan, Jakarta.

Sekaran, U. (2003). Towards a guide for novice research on research methodology: Review and proposed methods. Journal of Cases of Information Technology, 8(4), 24-35.

Shrivastava, P., \& Hart, S. (1995). Creating sustainable corporations. Business Strategy and the Environment, 4(3), $154-165$.

Stevenson, H., \& Jarillo, C. (1990). A paradigm of entrepreneurship as a field of research. Academy of Management Review, 3 , 45-57.

Sutamihardja (2004) Perubahan Lingkungan Global; Program Studi Pengelolaan Sumber Daya Alam dan Lingkungan Sekolah Pascasarjana; IPB.Sea Cipinang Besar Selatan.Jurnal Pemberdayaan Masyarakat Madani, Vol. 1, No.

Suryana. (2003). Kewirausahaan: Pedoman Praktis, Kiat dan Proses Menuju Sukses. Jakarta. Salemba Empat.

WCED, S. W. S. (1987). World commission on environment and development. Our common future, 17, 1-91.

Wirtenberg, J., Harmon, J., \& Fairfield, K. (2008). HR's role in building a sustainable enterprise: insights from some of world's best companies.-Entrepreneur. com. Business \& Small Business.

World Commission on Environment and Development, \& Brundtland, G. H. (1987). Presentation of the Report of the World Commission on Environment and Development to the Commission of the European Communities, the EC and EFTA Countries... 5 May 1987, Brussels. World Commission on Environment and Development.

Wijaya, T. (2013). Ekonomi dan Bisnis. Yogyakarta, Graha Ilmu.

Wiklund, J. (1999). The sustainability of the entrepreneurial orientation-performance relationship. Entrepreneurship theory and practice, 24(1), 37-48.

Wiklund, J., \& Shepherd, D. (2003). Knowledge-Based Resources, Entrepreneurial Orientation, And The Performance Of Small Medium-Sized Businesses. Strategic Management Journal(24), 1307-1314.

Yaghoobi, N. M., Salarzehi, H., Aramesh, H., \& Akbari, H. (2010). An evaluation of independent entrepreneurship obstaclesin industrial SMEs. European Journal of Social Sciences, 15(4), 512-520.

\section{Appendix 1}

Loading Factor Test Of Full Model

Results Loading Factors and t values of Full Model

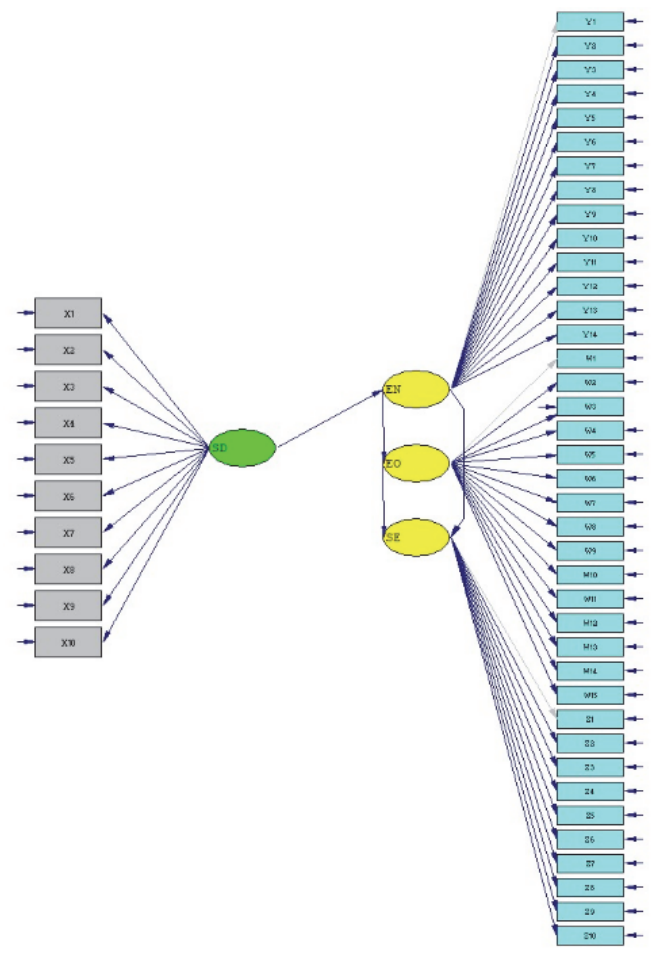


1. Variable Sustainable Development (SD)

\begin{tabular}{|c|c|c|}
\hline Sustainable Development & Loading Factor & t values \\
\hline X1 & 0.52 & 8.28 \\
X2 & 0.30 & 4.45 \\
X3 & 0.68 & 11.55 \\
X4 & 0.61 & 10.00 \\
X5 & 0.49 & 7.81 \\
X6 & 0.63 & 10.34 \\
X7 & 0.74 & 12.91 \\
X8 & 0.67 & 11.29 \\
X9 & 0.44 & 6.90 \\
X10 & 0.69 & 11.64 \\
\hline
\end{tabular}

3. Variable Entrepreneurship Orientation (EO)

\begin{tabular}{|c|c|c|}
\hline Orientation Entrepreneurship & Loading Factor & t values \\
\hline W1 & 0.73 & 0.00 \\
W2 & 0.78 & 12.25 \\
W3 & 0.76 & 11.99 \\
W4 & 0.78 & 12.22 \\
W5 & 0.81 & 12.74 \\
W6 & 0.76 & 11.90 \\
W7 & 0.72 & 11.22 \\
W8 & 0.75 & 11.76 \\
W9 & 0.52 & 7.99 \\
W10 & 0.59 & 9.25 \\
W11 & 0.80 & 12.62 \\
W12 & 0.60 & 9.39 \\
W13 & 0.77 & 12.16 \\
W14 & 0.62 & 9.69 \\
W15 & 0.44 & 6.85 \\
\hline
\end{tabular}

2. Variable Entrepreneur (EN)

\begin{tabular}{|c|c|c|}
\hline Entrepreneur & Loading Factor & t values \\
\hline Y1 & 0.76 & 0.00 \\
Y2 & 0.80 & 13.57 \\
Y3 & 0.77 & 12.91 \\
Y4 & 0.97 & 9.18 \\
Y5 & 0.36 & 5.64 \\
Y6 & 0.62 & 10.01 \\
Y7 & 0.78 & 13.04 \\
Y8 & 0.83 & 14.09 \\
Y9 & 0.76 & 12.77 \\
Y10 & 0.79 & 13.30 \\
Y11 & 0.83 & 14.20 \\
Y12 & 0.84 & 14.39 \\
Y13 & 0.81 & 13.68 \\
Y14 & 0.76 & 12.64 \\
\hline
\end{tabular}

4. Variable Sustainable Enterprise (SE)

\begin{tabular}{|c|c|c|}
\hline Sustainable Enterprise & Loading Factor & t values \\
\hline$Z 1$ & 0.69 & 0.00 \\
$Z 2$ & 0.70 & 10.28 \\
$Z 3$ & 0.76 & 11.15 \\
$Z 4$ & 0.81 & 11.80 \\
$Z 5$ & 0.83 & 12.07 \\
$z 6$ & 0.79 & 11.62 \\
$Z 7$ & 0.80 & 11.68 \\
$z 8$ & 0.70 & 10.34 \\
$z 9$ & 0.71 & 10.48 \\
$Z 10$ & 0.73 & 10.71 \\
\hline
\end{tabular}

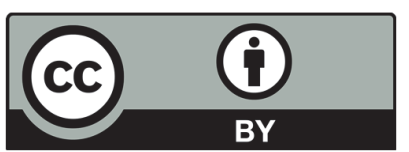

(C) 2020 by the authors; licensee Growing Science, Canada. This is an open access article distributed under the terms and conditions of the Creative Commons Attribution (CC-BY) license (http://creativecommons.org/licenses/by/4.0/). 